\title{
Analysis of Dynamics of Proteome in Resistant Cultivar of Pearl Millet Seedlings during Sclerospora graminicola Infection
}

\author{
Chandra Pal Anup, Kukkundoor Ramachandra Kini* \\ Department of Studies in Biotechnology, University of Mysore, Manasagangotri, Mysuru 570 006, Karnataka, India.
}

\section{ARTICLE INFO}

Article history:

Received on: 20/03/2016

Revised on: 09/04/2016

Accepted on: 14/04/2016

Available online: 21/04/2016

Key words:

Pearl millet, downy mildew, early expressing genes,

differential regulation,

proteomics.

\begin{abstract}
The current study was performed to analyze the dynamics of proteome in resistant cultivar of pearl millet seedlings during early hours of downy mildew infection. This was achieved using two-dimensional gel electrophoresis (2DE)-nano LCMS/MS based approach. Total protein extract from two-day-old pearl millet seedlings harvested $6 \mathrm{~h}$ post inoculation with pathogen, was fractionated by 2DE on 5-8 pI range IPG strips. Among the 210 protein spots detected by the PD-Quest software, 21 proteins were found to be up-regulated and 14 proteins down-regulated. Differential regulation of these proteins during downy mildew infection was found to be significant at $\mathrm{p} \leq 0.05$. Majority of these proteins belonged to the following functional categories: energy and metabolism (32\%) category as well as stress and defense (32\%). Unlike the previous proteomic study in pearl millet, the present study showed differential accumulation of early expressing defense-related genes such as those involved in reactive oxygen species mediated pathways, pathogenesis-related proteins and other interconnecting pathways responsible for coordinating the resistance mechanism of the plant. The current findings shed light on the vital differentially regulated proteins of pearl millet during early phase of pathogen infection that can be targeted as future disease management strategy.
\end{abstract}

\section{INTRODUCTION}

Pearl millet known as poor man's staple crop is grown in semi-arid tropical regions of Asia and Africa. India is the leading producer of the crop across the globe. Considering the food security issue into account, pearl millet will be one of the future crops due to its tolerant nature towards acidic soil as well as drought condition. In terms of health benefits, dieticians recommend the cereal intake due to its high iron and fibre content [1]. However, the plant is known to succumb to diseases such as rust and downy mildew, of which the latter caused by an obligate biotrophic oomycete- Sclerospora graminicola is known to reduce the crop yield by more than $80 \%$ [2]. Young seedlings infected by this pathogen results in plant with stunted growth, chlorotic leaves, malformed inflorescence (green-ear head) and powdery deposition of the pathogen (downy mildew) on the abaxial leaf surface. Despite breeding using resistant cultivars,

* Corresponding Author

K. Ramachandra Kini,Email: krk@appbot.uni-mysore.ac.in

Tel. No. : +91-0821-2419882; Fax: +91-821-2414450 the pathogen has managed to evolve and evade the plant defense machinery. Usage of fungicide such as strobilurin (azoxystrobin) was known to be effective in reducing the disease incidence level upto $93 \%$ but has an adverse impact on the environment [3].

This has enforced a need for an alternative strategy where the molecular mechanism consisting of the host proteins involved in resistance is deciphered. These functional protein molecules can then be targeted to generate transgenic lines with desired trait(s) for counteracting the pathogen.

In one of the previous proteomic studies in susceptible cultivar of pearl millet, the resistance mechanism conferred by elicitors which were responsible for reduction in downy mildew disease incidence level under field conditions by more than $70 \%$ was deciphered [4]. In the current study, two-dimensional gel electrophoresis (2DE) and nano-LC MS/MS based proteomic approach was performed to unravel the molecular basis of plant defense in the resistant cultivar of pearl millet especially during early phase of pathogen infection. The current study provides information on the early expressing genes of resistance that needs to be targeted as part of disease management strategy. 


\section{MATERIALS AND METHODS}

\subsection{Plant Material and Pathogen Inoculum Preparation}

Seeds of pearl millet (Pennisetum glaucum) cultivar IP18296 (highly resistant) with $0 \%$ disease incidence upon inoculation with $S$. graminicola under field conditions were chosen for the present study. Seeds were procured from International Crop Research Institute for Semi-Arid Tropics (ICRISAT), Telangana, India. For inoculation experiment, the pathogen was isolated from pearl millet HB3 cultivar maintained under greenhouse condition. Leaves exhibiting downy mildew symptoms were collected from the infected plants and washed under running tap water to remove previous crop of sporangia. The leaves were then blot-dried cut into 4 inches length and incubated overnight under moist conditions. Fresh crop of sporangia were then brushed from leaves in sterile water to make the zoospore suspension.

\subsection{Pathogen Inoculum}

Initially pearl millet seeds cv. IP18296 were surface sterilized using $0.1 \%$ sodium hypochlorite and washed with sterile water before incubating them under dark at $\pm 25^{\circ} \mathrm{C}$ on moist filter under aseptic condition. The two-day-old seedling was then inoculated with pathogen suspension of $4 \times 10^{4}$ zoospores $/ \mathrm{mL}$ [5]. The proteomic experiment performed on the analysis of pearl millet- downy mildew interaction was initially carried out by harvesting the seedlings at $0,6,12$ and 24 h.p.i. along with their mock-inoculated samples.

So among these samples, the early time point of post inoculation with the pathogen was $6 \mathrm{~h}$ and as per the objective of our study we decided to look into the early phase of changes in dynamics of proteome of pearl millet by considering this particular time point. The seedlings were then harvested 6 hours post inoculation (h.p.i.), snap frozen in liquid nitrogen and stored at $-80{ }^{\circ} \mathrm{C}$ until used for further analysis. Uninoculated water treated seedlings maintained in parallel served as control.

\subsection{Two-Dimensional Gel Electrophoresis (2DE) Based Fractionation of Proteins}

The total protein extraction from these seedlings was performed as described by [6]. Protein pellet obtained from the phenol based extraction was solubilized in lysis buffer ( $7 \mathrm{M}$ urea, $2 \mathrm{M}$ thiourea, 2\% CHAPS, $0.5 \%$ ampholytes $\mathrm{pH} \mathrm{3-10}$ and 2\% DTT) and quantified by modified Bradford method [7].

Consequently $400 \mu \mathrm{g}$ equivalent protein was loaded and subjected to active rehydration and iso-electric focusing on $17 \mathrm{~cm}$ IPG strip of $\mathrm{pI}$ range 5-8 using the program: $1 \mathrm{~h}$ at $1000 \mathrm{~V}$ and 2.5 $\mathrm{h}$ at $10,000 \mathrm{~V}$ and $10000 \mathrm{~V}$ maintained for $5 \mathrm{~h}$ (i.e. $50000 \mathrm{Vh}$ ) followed by incubation in equilibration buffer and fractionation on SDS-PAGE as per the manufacturer's instruction (ReadyStrip IPG, Bio-Rad). Protein spots on 2D gels were visualized using Coomassie blue stain [8]. The experiment was carried out in triplicates.

\subsection{Image Acquisition and 2D Gel Analysis}

Triplicate 2D gels derived from both 6 h.p.i. and the corresponding control samples were scanned using Gel doc-XR (Bio-Rad) followed by their analysis using PD-Quest software (v.8.01). Protein spot detection tool of the software detected the statistically significant (student t-test, $\mathrm{p} \leq 0.05$ ) and differentially regulated proteins (more than 2-fold changes in protein abundance) in 6 h.p.i. sample with respect to control sample. Densitometric based protein abundance determination by the software was estimated by normalizing the protein intensity of protein spots using total density in gel image as the normalizing factor. Normalized protein intensity of spots expressed in parts per million (ppm) was calculated as: (Intensity of a protein spot/Total density in gel image normalization factor) $\mathrm{X} 10^{6}$.

\subsection{Mass spectrometric analysis of proteins from 2D gels}

The statistically significant and differentially accumulated proteins detected by the software were manually excised from 2D gels and subjected to in-gel trypsin digestion [9] and the resulting peptides were desalted [10]. The desalted peptide mixture of each protein spot was analyzed using Agilent 1260 Infinity Nanoflow pump LC system coupled to Agilent 6550 iFunnel QTOF mass spectrometer (Agilent technologies) as described previously [3]. Mass spectrometry data obtained was exported as .mgf format and analyzed using MASCOT search engine and PEAKS denovo sequencing software [11]. Parameter adopted by these tools for protein identification from Swiss-Prot database using trypsin as enzyme specificity; number of missed cleavages as one; mass accuracy of $10 \mathrm{ppm}$ for peptide tolerance and $0.05 \mathrm{Da}$ for fragment tolerance; fixed modification as carbamidomethylation of cysteine residues and oxidation of methionine as variable modification. Taxonomy considered was Viridiplantae and decoy database employed in eliminating the possibility of false positives during protein identification process. Proteins identified were assigned functional category [12].

\section{RESULTS}

\subsection{Detection of Differentially Regulated Proteins in Pearl during Early Phase of Pathogen Infection in Resistant Cultivar of Pearl Millet}

Protein extract from the 6 h.p.i and its corresponding control sample which were fractionated by $2 \mathrm{DE}$ were distributed in the $\mathrm{pI}$ range of 5-8 and molecular mass of 14 to $116 \mathrm{kDa}$ (figure 1). The $2 \mathrm{D}$ gel analysis software (PD-Quest) detected 210 protein spots on the $2 \mathrm{D}$ gels of which 21 exhibited significant $(\mathrm{p} \leq 0.05)$ two-fold upregulation and 14 of them showed two-fold downregulation.

Fold-change values of the protein spots of pathogen inoculated samples w.r.t. control sample varied from 0.02 to 20 (table 1). Two-fold upregulation refers to the fold change value beyond 2.0 and two-fold down regulation refers to value below 0.50 . 


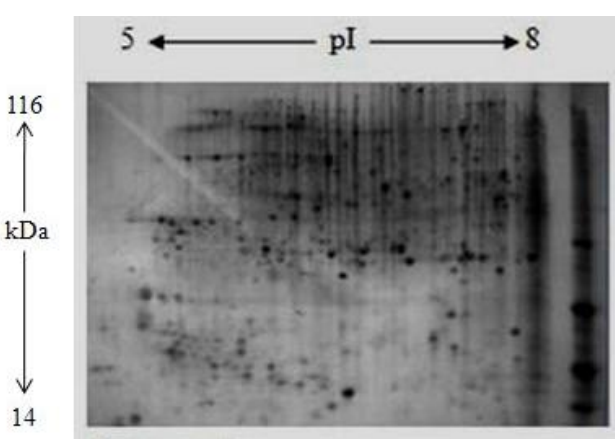

$6 \mathrm{~h}$ control

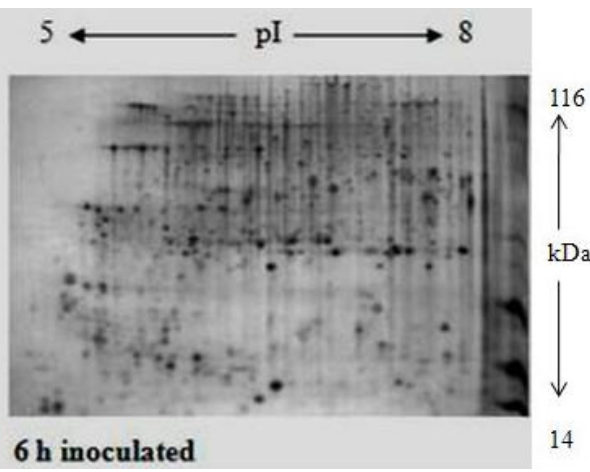

Fig. 1: Representation of 2D gel images from the replicates where the protein extract from 6 h.p.i. and its control sample was fractionated on immobilized pH gradient strips of iso-electric point range between 5 to 8 in one dimension followed by its subsequent separation in second dimension on a $12 \%$ polyacrylamide gel by SDS-PAGE.

Table 1: Details of the differentially accumulated proteins identified by nano-LC MS/MS analysis.

\begin{tabular}{|c|c|c|c|c|c|c|}
\hline $\begin{array}{l}\text { Sl. } \\
\text { No. }\end{array}$ & $\begin{array}{l}\text { Homologous } \\
\text { protein }\end{array}$ & $\begin{array}{l}\text { Reference } \\
\text { organism (UniProt } \\
\text { accession ID) }\end{array}$ & $\begin{array}{l}\text { Unique peptide } \\
\text { sequence matches }\end{array}$ & $\begin{array}{c}\text { MASCOT } \\
\text { /PEAKS } \\
\text { score } \\
(\mathbf{p} \leq 0.01)\end{array}$ & Functional category & $\begin{array}{r}\text { Fold change } \\
(p \leq 0.01)\end{array}$ \\
\hline 1 & $\begin{array}{l}\text { Proteasome subunit alpha } \\
\text { type }\end{array}$ & $\begin{array}{l}\text { Setaria italica } \\
\text { (K3XLA2_SETIT) }\end{array}$ & $\begin{array}{l}\text { ALTTEEIDQHLTAISER; } \\
\text { ATSAGLKEQEAINFLEK; } \\
\text { GKDSVCVVTQK; ATEIEVGVVRK }\end{array}$ & 54 & $\begin{array}{l}\text { Protein destination and } \\
\text { storage }\end{array}$ & 0.45 \\
\hline 2 & $\begin{array}{l}\text { Isocitrate dehydrogenase } \\
\text { [NADP] }\end{array}$ & $\begin{array}{l}\text { Setaria italica } \\
\text { (K3Y6V4_SETIT) }\end{array}$ & $\begin{array}{l}\text { DATDDKVTVEAAEATLK; } \\
\text { TIEAEAAHGTVTR; } \\
\text { ATDAVLKGPGK }\end{array}$ & 39 & $\begin{array}{l}\text { Energy and } \\
\text { metabolism }\end{array}$ & 2.15 \\
\hline 3 & $\begin{array}{l}\text { Fructose-bisphosphate } \\
\text { aldolase, cytoplasmic }\end{array}$ & $\begin{array}{l}\text { Setaria italica } \\
\text { (K3XIT0_SETIT) }\end{array}$ & $\begin{array}{l}\text { IGPNEPSQLAIDLNAQGLAR; } \\
\text { KVTPEVIAEYTVR }\end{array}$ & 27 & $\begin{array}{l}\text { Energy and } \\
\text { metabolism }\end{array}$ & 0.32 \\
\hline 4 & Chitinase & $\begin{array}{l}\text { Pennisetum glaucum } \\
\text { (D8V069_PENAM) }\end{array}$ & $\begin{array}{l}\text { SAFLEAANK; FCYISEINK; } \\
\text { GPLQISWNYNYGPR }\end{array}$ & 30 & Stress and defense & 3.0 \\
\hline 5 & Ascorbate peroxidase & $\begin{array}{l}\text { Pennisetum glaucum } \\
\text { (Q5MJ31_PENAM) }\end{array}$ & $\begin{array}{l}\text { TGGPFGTMK; NPAEQAHGANAGLDIAVR; } \\
\text { SGFEGPWTR }\end{array}$ & 41 & Stress and defense & 20.0 \\
\hline 6 & Nucleic acid-binding protein & $\begin{array}{l}\text { Zea mays } \\
\text { (Q41834_MAIZE) }\end{array}$ & $\begin{array}{l}\text { VYVGNLPYDVDSER; GFGF } \\
\text { VTMSTVEEAEK; } \\
\text { VNVAEER; ETDQSR }\end{array}$ & 39 & Protein synthesis & 0.38 \\
\hline 7 & $\begin{array}{l}\text { Ribulosebisphosphate } \\
\text { carboxylase, large subunit } \\
\text { (chloroplast) }\end{array}$ & $\begin{array}{l}\text { Pennisetum glaucum } \\
\text { (R4I6V3_PENAM) }\end{array}$ & $\begin{array}{l}\text { LTYYTPEYETK; } \\
\text { IPPSYSK }\end{array}$ & 24 & $\begin{array}{l}\text { Energy and } \\
\text { metabolism }\end{array}$ & 0.28 \\
\hline 8 & Xylanase inhibitor protein 1 & $\begin{array}{l}\text { Oryza sativa } \\
\text { japonica } \\
\text { (XIP1_ORYSJ) }\end{array}$ & $\begin{array}{l}\text { TGQVTVFWGR; CAFPDPR; } \\
\text { NYGGIMLWDR; QLYYDLLPNVQK }\end{array}$ & 58 & Stress and defense & 0.47 \\
\hline 9 & $\begin{array}{l}\text { Guanine nucleotide-binding } \\
\text { protein beta subunit-like } \\
\text { protein }\end{array}$ & $\begin{array}{l}\text { Zea mays } \\
\text { (B4FKM1_MAIZE) }\end{array}$ & $\begin{array}{l}\text { GHNGEVTAIATPIDNSPFIVSSSR; } \\
\text { HVVQDLKPDIQISK; LWDLSTGLTTR; } \\
\text { DVISVAFSVDNR }\end{array}$ & 63 & Signal transduction & 3.15 \\
\hline 10 & $\begin{array}{l}\text { Ferredoxin--NADP } \\
\text { reductase }\end{array}$ & $\begin{array}{l}\text { Zea mays } \\
\text { (Q41736_MAIZE) }\end{array}$ & $\begin{array}{l}\text { LYSIASSALGDFGDSK; } \\
\text { VLCMSVQQASR; IEEYSD EIFK; } \\
\text { PGAPQNVR }\end{array}$ & 38 & $\begin{array}{l}\text { Energy and } \\
\text { metabolism }\end{array}$ & 0.33 \\
\hline 11 & $\begin{array}{l}\text { Xyloglucan } \\
\text { endotransglucosylase/hydrol } \\
\text { ase }\end{array}$ & $\begin{array}{l}\text { Setaria italica } \\
\text { (K3Y1W8_SETIT) }\end{array}$ & $\begin{array}{l}\text { ILDGGQLLTLSMDR; } \\
\text { NLAASAAGVPFPTSQPMR }\end{array}$ & 32 & $\begin{array}{l}\text { Protein destination and } \\
\text { storage }\end{array}$ & 11.0 \\
\hline 12 & Isocitrate lyase & $\begin{array}{l}\text { Setaria italica } \\
\text { (K3ZRW1_SETIT) }\end{array}$ & $\begin{array}{l}\text { APYVDFLKPIIADGDTGFGGATATVK } \\
\text { GAAGVHLEDQSSVTKK; } \\
\text { TDAVAATLIQTNVDAR; VLVAVSEHVNR }\end{array}$ & 72 & $\begin{array}{l}\text { Energy and } \\
\text { metabolism }\end{array}$ & 15.8 \\
\hline 13 & $\begin{array}{l}\text { Phosphoenolpyruvate } \\
\text { carboxykinase }\end{array}$ & $\begin{array}{l}\text { Pennisetum glaucum } \\
\text { (H8WG36_PENAM) }\end{array}$ & $\begin{array}{l}\text { DGDVALFFGLSGTGK; AAYPIEYIPNAK; } \\
\text { IPCVGPHPK; } \\
\text { YAAMLAEK; CIDLSR; SVTENTR } \\
\end{array}$ & 58 & $\begin{array}{l}\text { Energy and } \\
\text { metabolism }\end{array}$ & 7.6 \\
\hline 14 & NBS-LRR-like protein & $\begin{array}{l}\text { Pennisetum glaucum } \\
\text { (Q8LKI6_PENAM) }\end{array}$ & LLADHASPSR; AIGVEDVHK & 41 & Stress and defense & 2.8 \\
\hline 15 & $\begin{array}{l}\text { Chloroplast heat shock } \\
\text { protein } 70\end{array}$ & $\begin{array}{l}\text { Pennisetum glaucum } \\
\text { (A4ZYQ0_PENAM) }\end{array}$ & $\begin{array}{l}\text { IAALEVLR; IINEPTAASLAYGFEK; } \\
\text { HIETTLTR; TTPSVVAYTK }\end{array}$ & 48 & Stress and defense & 5.9 \\
\hline 16 & $\begin{array}{l}\text { Glyceraldehyde-3-phosphate } \\
\text { dehydrogenase }\end{array}$ & $\begin{array}{l}\text { Pennisetum glaucum } \\
\text { (D9YMC4_PENAM }\end{array}$ & $\begin{array}{l}\text { KVIISAPSK; AASYEDIKK } \\
\text { AASFNIIPSSTGAAK; LTGMSFR }\end{array}$ & 39 & $\begin{array}{l}\text { Energy and } \\
\text { metabolism }\end{array}$ & 3.4 \\
\hline 17 & $\begin{array}{l}\text { Ricin B lectin } 2 \text { family } \\
\text { protein }\end{array}$ & $\begin{array}{l}\text { Zea mays } \\
\text { (B4G0K5_MAIZE) }\end{array}$ & $\begin{array}{l}\text { HSLGQSHPVK; DEYQHWIK; } \\
\text { LNFDAFHGDK; DGTNIVLWK }\end{array}$ & 52 & Stress and defense & 0.41 \\
\hline 18 & Alpha-amylase & $\begin{array}{l}\text { Setaria italica } \\
\text { (K3XX03_SETIT) }\end{array}$ & $\begin{array}{l}\text { GILNAAVEGELWR; } \\
\text { QALVDWVDK; DYAVWEK } \\
\end{array}$ & 29 & $\begin{array}{l}\text { Protein destination and } \\
\text { storage }\end{array}$ & 6.50 \\
\hline 19 & $\begin{array}{l}\text { GTP binding nuclear } \\
\text { protein-Ran }\end{array}$ & $\begin{array}{l}\text { Zea mays } \\
\text { (C0HHC1_MAIZE) }\end{array}$ & $\begin{array}{l}\text { VCENIPIVLCGNK; HLTGEFEK; } \\
\text { NLQYYEISAK; FYCWDTAGQEK }\end{array}$ & 55 & Transport & 4.20 \\
\hline 20 & $\begin{array}{l}\text { Glutathione S-transferase 4- } \\
\text { like }\end{array}$ & $\begin{array}{l}\text { Setaria italica } \\
\left(\mathrm{XP} \_004960284.1\right)\end{array}$ & $\begin{array}{l}\text { ALLALEEAGVDYELVPMSR; } \\
\text { VYGWAISPFVSR; KVLEVYEAR; } \\
\text { ALLALEEAGVDYELVPMSR }\end{array}$ & 42 & Stress and defense & 0.35 \\
\hline
\end{tabular}




\begin{tabular}{|c|c|c|c|c|c|c|}
\hline 21 & $\begin{array}{l}\text { Eukaryotic translation initiation } \\
\text { factor } 4 \mathrm{E}-1\end{array}$ & $\begin{array}{l}\text { Zea mays } \\
\text { (IF4E1_MAIZE) }\end{array}$ & NAANEAAQVSIGK; WEDPICANGGK & 28 & Protein synthesis & 2.5 \\
\hline 22 & Catalase & $\begin{array}{l}\text { Setaria italica } \\
\text { (K3XW81_SETIT) }\end{array}$ & $\begin{array}{l}\text { APGVQTPVIVR; GPILLEDYHLIEK; } \\
\text { FPDMVHAFK }\end{array}$ & 34 & Stress and defense & 4.5 \\
\hline 23 & Actin & $\begin{array}{l}\text { Zea mays } \\
\text { (B4F989_MAIZE) }\end{array}$ & $\begin{array}{l}\text { AEYDESGPSIVHR; GYSFTTTAER; } \\
\text { AEYDESGPSIVHRK; CDVDIRK }\end{array}$ & 64 & Cell structure & 3.80 \\
\hline 24 & Phosphoglycerate kinase & $\begin{array}{l}\text { Zea mays } \\
\text { (B4G0K4_MAIZE) }\end{array}$ & $\begin{array}{l}\text { KLAELTTTK; KPFAAIVGGSK; } \\
\text { SVGTLGEADLK; LAELTTTK }\end{array}$ & 42 & Energy and metabolism & 0.29 \\
\hline 25 & Transaldolase 2 & $\begin{array}{l}\text { Zea mays } \\
\text { (B4FRC9_MAIZE) }\end{array}$ & $\begin{array}{l}\text { LANDTQGTVEAAK; LLWASTGVR; } \\
\text { SF DSLLVSLQEK; }\end{array}$ & 36 & Energy and metabolism & 0.33 \\
\hline 26 & Elongation factor $\mathrm{Tu}$ & $\begin{array}{l}\text { Setaria italica } \\
\text { (K3YS75_SETIT) }\end{array}$ & $\begin{array}{l}\text { PHVNIGTIGHVDHGK; } \\
\text { GDTVDIVGR; TVGAGVINK; }\end{array}$ & 49 & Protein synthesis & 0.44 \\
\hline 27 & Ferritin-1, chloroplastic & $\begin{array}{l}\text { Zea mays } \\
\text { (FRI1_MAIZE) }\end{array}$ & $\begin{array}{l}\text { LQSIVTPLTEFDHPEK; FFKESSDEER; } \\
\text { GDALYAMELALALEK; }\end{array}$ & 38 & Transport & 6.89 \\
\hline 28 & $\begin{array}{l}\text { calcium permeable stress-gated } \\
\text { cation channel 1-like isoform X2 }\end{array}$ & $\begin{array}{l}\text { Zea mays } \\
\left(\mathrm{XP} \_008674130.1\right)\end{array}$ & $\begin{array}{l}\text { YAALIASEILQTSNPMK; } \\
\text { ESCSDVVDNFFTK; DIPVQLAK; }\end{array}$ & 37 & Stress and defense & 13.5 \\
\hline
\end{tabular}

\subsection{Identification of the Differentially Regulated Proteins by Nano-LC MS/MS Analysis}

Among the 35 protein spots which exhibited differential regulation only 28 proteins ( $80 \%$ ) were successfully identified by MS/MS analysis. Analysis of the mass spectrometry data using protein databases of NCBI and Swiss-Prot using MASCOT search engine revealed that the most of the protein matches belonged to monocot family especially that of foxtail millet (29\%), maize $(36 \%)$, rice $(4 \%)$ and pearl millet $(21 \%)$. In addition, protein database of these plant species were downloaded from NCBI and uploaded into de novo sequencing software- PEAKS further confirmed the significance level at which protein matched to the databases based on the FDR (false-discovery rate) of $\leq 0.1$ and PEAKS score $[-10 \log (p-$ value $)]$ was beyond $20(p \leq 0.01)$. All the proteins identified, matched to the database with atleast two peptide hits and a score beyond 20 (table 1). Among the proteins identified majority of them belonged to energy and metabolism $(32 \%)$ and stress and defense category $(32 \%)$ followed by proteindestination and storage $(11 \%)$, protein synthesis $(11 \%)$, transport (6\%), signal transduction (4\%) and cell structure (4\%) (figure 2).

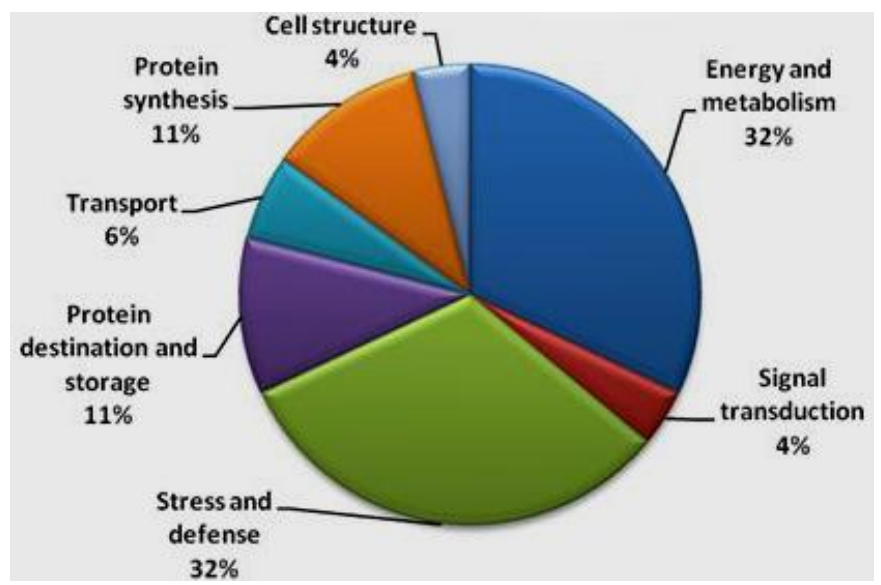

Fig. 2: Distribution of the differentially accumulated proteins of pearl millet under varied functional categories during the early hours of pathogen infection.

\section{DISCUSSION}

The present study is the first to report on the proteome dynamics of a resistance cultivar of pearl millet during its initial phase of interaction with Sclerospora graminicola. Proteomic analysis of pearl millet was a challenge in terms of protein identification due to limited protein entries of the host in public databases such as NCBI. Thus homology based protein identification was adopted using protein database of closely related species such as rice, maize, wheat and foxtail millet [13]. It is observed that, most of the protein matches were against protein database of maize and foxtail millet rather than pearl millet. This could be attributed to genome of pearl millet which is not yet sequenced and consequently limited protein entries of pearl millet in public databases such as NCBI and SwissProt is observed. From the present study equal proportion of proteins related to energy and metabolism as well plant defense category was found to be differentially regulated suggesting the balance that is being maintained in energy diversion towards normal metabolism as well as towards pathways associated with stress, so that normal physiology of the plant is not compromised. This observation could be attributed to the resistant cultivar of the plant.

In contrast to previous proteomic study in pearl millet [3], some of the early expressing genes associated with plant defense such as ascorbate peroxidase, catalase, calcium permeable stress-gated cation channel, NBS-LRR resistance protein which are transiently expressed were found to be up regulated by $20,4.5$, 13.5 and 2.8 folds respectively, at $\mathrm{p} \leq 0.05$. This could be explained by the fact that the plant during its initial encounter with pathogen conveys the signal mediated by resistance protein inturn activating the calcium ion channels of the cell membrane and the resulting intracellular ion flux activates the reactive oxygen species (ROS) pathway under stress caused by pathogen attack [14]. Consequently, hypersensitive response (HR) is ensued that causes localized cell death at the site of pathogen entry and prevents its further invasion. However, it is important to note that ROS generated under stress condition as a part of HR, needs to be regulated, which otherwise has an adverse impact on the host plant. This regulation is performed by ROS scavenging enzymes such as catalase, which is one among the differentially upregulated proteins identified in our analysis.

In addition, unlike the previous study, the present work detected proteins associated with secondary metabolism among the differentially regulated proteins. This suggests that proteins of secondary metabolic processes such as phenylalanine ammonia lyase (PAL) and 12-oxophytodienoate reductase which are 
involved in the systemic acquired resistance (SAR) as detected in previous proteomic study were not activated during early phase of pathogen infection [15]. Pathogenesis related-proteins such as chitinase was found to be 3-fold up regulated but the xylanaseinhibitor protein and glutathione S-transferase that are associated with plant defense were down-regulated by 0.47 and 0.35 folds respectively. Even, the constitutively expressing protein- actin was found to be 3.8 folds up-regulated, probably involved in trafficking of defense compounds at the site of pathogen entry [16]. Thus, it is important to note that based on the early phase of defense response events conferred by early expressing genes, maximum differential response in the host occurs at later phase of post infection leading to systemic immunity in plants (SAR) [17]. This mode of resistance mechanism is indicated in our study based on the differential response of the early expressing genes involved in ROS-mediated HR. Up-regulation or down-regulation of proteins belonging to each of the functional categories indicates that a complex network of protein-protein interaction exists in pearl millet which plays a role in its resistance mechanism of the resistant cultivar during its interaction with downy mildew pathogen. However, the study has narrowed down the search for proteins that can be targeted during development of transgenic lines bearing the traits of resistant cultivars. Moreover, functional analysis by performing knock-out studies would further unravel precise role of these differentially regulated proteins during downy mildew infection.

\section{CONCLUSION}

The present study provides significant insight on the dynamics of pearl millet proteome during early hours of downy mildew infection. Moreover, the study proposes regulated ROSmediated HR involved during the initial phase of resistance of the host. The study lays a foundation for further experimental studies such as functional analysis (which is under investigation) and thereby developing an effective disease management strategy to counteract the evolving oomycete infection.

\section{ACKNOWLEDGEMENTS}

The author ACP would like to thank the DBT-JRF programme, Govt. of India for supporting with the fellowship. We would like to thank IIT-Bombay and Institute of Bioinformatics, Bangalore, for providing technical assistance during mass spectrometric analysis. We acknowledge the recognition of University of Mysore as an Institution of Excellence by the Government of India under MHRD-UGC programme for providing the infrastructure to perform the $2 \mathrm{D}$-gel experiments.

\section{REFERENCES}

1. Balasubramanian S, Singh KK, Patil RT, Onkar KK. Quality evaluation of millet-soy blended extrudates formulated through linear programming. J Food Sci Technol 2012; 49(4):450-8.

2. Yadav RS, Hash CT, Bidinger FR, Cavan GP, Howarth CJ. Quantitative trait loci associated with traits determining grain and stover yield in pearl millet under terminal drought-stress conditions. Theor Appl Genet 2002; 104(1):67-83.

3. Sudisha J, Amruthesh KN, Deepak SA, Shetty NP, Sarosh BR, Shetty HS. Comparative efficacy of strobilurin fungicides against downy mildew disease of pearl millet. Pesticide Biochemistry and Physiology. 2005 Mar 31;81(3):188-97.

4. Anup CP, Melvin P, Shilpa N, Gandhi MN, Jadhav M, Ali H, et al. Proteomic analysis of elicitation of downy mildew disease resistance in pearl millet by seed priming with $\beta$-aminobutyric acid and Pseudomonas fluorescens. J Proteomics; 2015;120:58-74.

5. Safeeulla KM. Biology and control of the downy mildews of pearl millet, sorghum and finger millet. Biol Control downy mildews pearl millet, sorghum finger millet. Mysore University;1976.

6. Hurkman WJ, Tanaka CK. Solubilization of Plant Membrane Proteins for Analysis by Two-Dimensional Gel Electrophoresis. 1986; 802-6.

7. Ramagli LS, Rodriguez L V. Quantitation of microgram amounts of protein in two-dimensional polyacrylamide gel electrophoresis sample buffer. Electrophoresis 1985; 6(11):559-63.

8. Wang $\mathrm{X}$, Wang D, Wang D, Wang H, Chang L, Yi X, et al. Systematic comparison of technical details in CBB methods and development of a sensitive GAP stain for comparative proteomic analysis. Electrophoresis. 2012; 33(2):296-306.

9. Shevchenko A, Tomas H, Havlis J, Olsen J V, Mann M. In-gel digestion for mass spectrometric characterization of proteins and proteomes. Nat Protoc. 2006; 1(6):2856-60.

10. Ishihama Y, Rappsilber J, Mann M. Modular Stop and Go Extraction Tips with Stacked Disks for Parallel and Multidimensional Peptide Fractionation in Proteomics. 2006; 988-94.

11. Zhang J, Xin L, Shan B, Chen W, Xie M, Yuen D, et al. PEAKS DB: de novo sequencing assisted database search for sensitive and accurate peptide identification. Mol Cell Proteomics. 2012; 11(4): M111.010587.

12. Bevan M, Bancroft I, Bent E, Love K, Goodman H, Dean C, et al. Analysis of $1.9 \mathrm{Mb}$ of contiguous sequence from chromosome 4 of Arabidopsis thaliana. Nature. Nature Publishing Group; 1998; 391(6666):485-8.

13. Zhang G, Liu X, Quan Z, Cheng S, Xu X, Pan S, et al. Genome sequence of foxtail millet (Setaria italica) provides insights into grass evolution and biofuel potential. Nat Biotechnol 2012; 30(6):549-54.

14. Cipriano AK, Gondim DM, Vasconcelos IM, Martins JA, Moura AA, Moreno FB, Monteiro-Moreira AC, Melo JG, Cardoso JE, Paiva AL, Oliveira JT. Proteomic analysis of responsive stem proteins of resistant and susceptible cashew plants after Lasiodiplodia theobromae infection. Journal of proteomics. 2015 Jan 15; 113:90109.

15. Wang Y, Loake GJ, Chu C. Cross-talk of nitric oxide and reactive oxygen species in plant programed cell death. Front Plant Sci 2013; $4: 314$.

16. Henty-Ridilla JL, Li J, Day B, Staiger CJ. ACTIN DEPOLYMERIZING FACTOR4 regulates actin dynamics during innate immune signaling in Arabidopsis. Plant Cell 2014; 26(1):34052.

17. Kawano T. Crosstalk between intracellular and extracellular salicylic acid signaling events leading to long-distance spread of signals. $2013 ; 1125-38$.

\section{How to cite this article:}

Anup CP, Kini KR. Analysis of Dynamics of Proteome in Resistant Cultivar of Pearl Millet Seedlings during Sclerospora graminicola Infection. J App Biol Biotech. 2016; 4 (02): 067-071. DOI: $10.7324 / J A B B .2016 .40210$ 